Aksaray University
Journal of Science and Engineering
e-ISSN: $2587-1277$
Web: $\underline{\text { http://asujse.aksaray.edu.tr }}$

Research Article

\title{
Determination of Fatty Acid Composition and Phenolic Content of Seed Oils of Cappadocia Region Grape Varieties
}

\author{
Selcuk Mustafa Secen* \\ Department of Food Engineering, Nevşehir Hacı Bektaş Veli University, Nevşehir 50300, Turkey
}

-Received Date: 07 Mar 2017

-Revised Date: 29 Mar 2017

-Accepted Date: 30 Mar 2017

-Published Online: 03 Apr 2017

\begin{abstract}
The grape (Vitis vinifera) from the Vitaceae family is the most grown fruit species in the world. Turkey has an important place in the world wine-growing due to favourable climatic conditions. The Cappadocia region is among the most important regions in Turkish wine production. The most grown varieties in this region are Emir and Dimrit grapes. Grape seeds are a by-product of the wine-making industry and fruit juice. Most of the total amount of grapes is used in wine making. In a few weeks of the harvest season, around 10 million tons of grape seeds are emerging in the world. Grape seed oil contains omega 6 , which is essential for omega fatty acids, at a high rate and also they are rich in polyphenolic compounds with strong biological effects. Due to the fatty acids and phenolic content of these products, it is aimed to be a new food source for human nutrition and at the same time to contribute to the reduction of factory product costs. The highest fatty acids identified in all varieties were linoleic acid (C18: 2), followed by oleic acid (C18: 1), palmitic acid (C16: 0) and stearic acid (C18: 0). Total phenolic substance content ranges between 70 and 84 (g GAE/kg extract) among the varieties. The phenolic content of the Dimrit grape seed is higher than Emir Grape seeds. According to these results, the oils of Cappadocia grape varieties Emir and Dimrit can be proposed as a new food source for human nutrition at the same time to contribute to the reduction of factory product costs.
\end{abstract}

Keywords

Grape, Cappadocia, Emir, Dimrit, Fatty Acid Composition

*Corresponding Author: Selçuk Mustafa SEÇEN, mustafasecen@nevsehir.edu.tr

2017@Published by Aksaray University 


\section{INTRODUCTION}

The grape (Vitis vinifera) from the Vitaceae family is the most grown fruit species in the world [1]. Turkey has an important place in the world winegrowing due to favourable climatic conditions [2]. $40 \%$ of the grape produced in our country is consumed as table, $35 \%$ is dried, $23 \%$ is used in making various products such as molasses, pulp, must and $2 \%$ is processed in wine [3]. Approximately $71 \%$ of world grape production is evaluated as wine, $27 \%$ as table and $2 \%$ as dry [4]. The Cappadocia region is among the most important regions in Turkish wine production. The most grown varieties in this region are Emir and Dimrit grapes.

Grape seeds are a by-product of the wine-making industry and fruit juice. Most of the total amount of grapes is used in wine making. In a few weeks of the harvest season, around 10 million tons of grape seeds are emerging in the world [5]. Seeds of grape constitute about $20 \%$ of the total weight of grapes [6]. Annual grape seed production capacity in Turkey is estimated to be about 30000 tons [2].

Only seeds are used for the production of grape seed oil, with about 7-20\% of the seed being oil based on dry matter [7]. Grape seed oil contains omega 6, which is essential for omega fatty acids, at a high rate. It is important that grape seed oil increase the HDL cholesterol (good) level and reduce the LDL cholesterol (bad) level. Grape seed oil contains unsaturated fatty acids such as linoleic acid (72-76\%) that makes it so precious. Grape seed contains more linoleic acid than most plants containing linoleic acid such as safflower (70-72\%), sunflower oil (60-62\%) and corn oil $(50-52 \%)$ [8].

Grape seeds are rich in polyphenolic compounds with strong biological effects. These polyphenols, which are composed of flavonoids and phenolic acids, have antioxidant, antibacterial and antiulcer activity [9]. In addition, the phenolic compounds in grape seeds also exhibit various physiological effects such as cardioprotective, anticancerogenic, antihypertension and antihyperglycemic [10-12]. Grape seeds, the compounds it contains and the physiological effects it has done have revealed the potential for use as food additives and supplements $[13,14]$.

In this study, it is aimed to investigate fatty acid compositions and total phenol contents of grape seeds extracted from Cappadocia region grapes and to evaluate unaccounted waste of wine, grape juice and molasses plants. Due to the fatty acids and phenolic content of these products, it is aimed to be a new food source for human nutrition and at the same time to contribute to the reduction of factory product costs. 


\section{MATERIALS AND METHOD}

\subsection{Grape Seeds}

The Emir and Dimrit grape varieties belonging to Cappadocia region were collected from the producer vineyards at the harvest time of 2016. Seeds are separated from their beads in the shadow and room temperature and waited for 10 days at room temperature until analysis.

\subsection{Analyses in Grape Seeds}

Moisture, ash, protein, total fat, total sugar was analysed in grape seed samples. The principle of moisture determination is to determine the water loss by drying the sample for a certain period at normal atmospheric pressure and calculate it as \% wet basis [15]. Ash is minerals that do not burn in food. In the analysis, the samples were brought to constant weight in an ash oven at $550{ }^{\circ} \mathrm{C}$ and cooled in a desiccator and then weighed [16]. Protein determination was made according to the principle of Kjeldahl method [17]. The principle of the oil is determined according to the Soxhlet method. The principle is to extract the substances soluble in the petroleum ether in the material, then to separate the petroleum ether and calculate the amount of the crude oil [18]. Total sugar analysis was performed by spectrophotometric method [19].

\subsection{Analyzes in Grape Seed Oils}

\subsubsection{Fatty acid analyzes}

Grape seeds were dried at $40^{\circ} \mathrm{C}$ for 3 hours, and then the moisture was reduced to $4 \%$ and then ground using mortar. For oil extraction from grape seeds, $5 \mathrm{~g}$ of the sample taken using the Soxhlet system was subjected to oil extraction with the help of hexane solvent. Solvent was evaporated in the evaporator and the amount of oil obtained was weighed and yielded. Fatty acids were determined by Agilent-6890N brand gas chromatograph. The derivatization process is described by Slower et al. method [20]. Fatty acid methyl ester (FAME) standards are used. Experimental conditions which the GC-FID spectrum of oils is obtained: Temperature 1: $60^{\circ}$ $\mathrm{C}$, Time 1: 2 minutes, Rate: $5^{\circ} \mathrm{C} /$ minute, Temperature 2: $250{ }^{\circ} \mathrm{C}$, Total analysis time: 60 minutes, Amount of sample injected: 1 microliter, Injector temperature: $230{ }^{\circ} \mathrm{C}$, Capillary column: HP-5 column ( $30 \mathrm{~m}$ in length, $0.32 \mathrm{~mm}$ in diameter, film thickness $0.25 \mu \mathrm{m}$ ), Carrier gas: hydrogen, 13.38 psi.

\subsubsection{Total phenolic compound analysis}

Using the Folin-Ciocalteu reagent, the total phenol compounds were measured for their absorbance at $760 \mathrm{~nm}$ in a spectrophotometer (Shimadzu UV-1601). Appropriate standard (gallic acid) solutions were prepared and the calibration graph was drawn by measuring the 
absorbance in the spectrophotometer. The total phenolic compound in the sample was determined from the correct equation obtained from the calibration graph [21].

\subsection{Statistical Analysis}

The trial was carried out in 3 replicates according to the $2 \times 2$ factorial trial plan based on the full chance and the data obtained on the basis of the research were subjected to analysis of variance using the SPSS package program. The averages for the variation sources were compared using the Duncan Multiple Comparison Test [22].

\section{RESULTS AND DISCUSSIONS}

Moisture, ash, protein, sugar values of seed samples used in the experiment are given in Table 1.

Table 1. Moisture, ash, protein, sugar values of grape seed (Data were averages of three different samples \pm standard deviation. Values followed by different letters in each row indicated significant differences $(\mathrm{p}<0.05)$ among different treatments.)

\begin{tabular}{lllc}
\hline & Emir & Dimrit & Level of Significance \\
\hline Moisture (\%) & $9.79 \pm 0.11 \mathrm{a}$ & $9.02 \pm 0.03 \mathrm{~b}$ & $* *$ \\
Ash $(\%)$ & $3.33 \pm 0.02 \mathrm{a}$ & $3.35 \pm 0.01 \mathrm{a}$ & N.S. \\
Protein $(\%)$ & $7.99 \pm 0.02 \mathrm{~b}$ & $8.70 \pm 0.02 \mathrm{a}$ & $* *$ \\
Sugar $(\mathrm{g} / 100 \mathrm{~g})$ & $11.36 \pm 0.30 \mathrm{a}$ & $11.34 \pm 0.21 \mathrm{a}$ & N.S. \\
\hline ** Significant at $\mathrm{p}<0.01$, N.S.: Non-Significant & &
\end{tabular}

When moisture, ash, protein, sugar values are examined; it is observed that the moisture content of Emir grape seeds and protein content of Dimrit grape seed is higher than the other (see Table 1). There was no statistical difference between ash and sugar amounts of grape seeds.

Both grape seeds generally have ash content higher than apple fiber and oat flour but lower than wheat flour when the literature is examined. In a study of the composition of grape pulp, the content of protein in the grape bark was reported to be 11.6-14.4 g / $100 \mathrm{~g}$ dry sample and ash content in grape bark 5.7-9.2 g/ $100 \mathrm{~g}$ dry sample [23]. When these values are examined, it is seen that both protein and ash contents of grape seeds are lower than grape pod contents.

The amounts of fatty acids, total fat and phenolic content of grape seeds are given in Table 2. The amount of saturated fat( $\left.\sum \mathrm{SFA}\right)$ is between $14.02 \%$ and $14.33 \%$. The sum of mono( $(M \mathrm{MUFA})$ and polyunsaturated ( $\sum$ PUFA) fatty acid amounts is $85.67 \%$ to $85.98 \%$. The amounts of saturated fatty acids are lower than the amounts of mono- and polyunsaturated fatty acids. The highest fatty acids identified in all varieties were linoleic acid (C18: 2), followed by oleic acid (C18: 1), palmitic acid (C16: 0) and stearic acid (C18: 0). The high amount of linoleic 
acid makes the grape seed oil valuable [7]. The amount of linoleic, oleic and palmitic acid in the Dimrit grape is higher than the Emir $(\mathrm{p}<0,05)$. The amount of stearic acid in the Emir grape is higher than the Dimrit ( $<<0,05)$. In terms of linoleic, oleic, palmitic and stearic acid content, the difference between the varieties is statistically significant.

Table 2. The amounts of fatty acids, total fat and phenolic content of grape seeds (Data were averages of three different samples \pm standard deviation. Values followed by different letters in each row indicated significant differences $(\mathrm{p}<0.05)$ among different treatments)

\begin{tabular}{lcccc}
\hline \multicolumn{1}{c}{ Fatty Acid Profile } & & Emir & Dimrit & $\begin{array}{c}\text { Level of } \\
\text { Significance }\end{array}$ \\
\hline Myristic acid (\%) & C14:0 & $0.12 \pm 0.01 \mathrm{a}$ & $0.09 \pm 0.01 \mathrm{~b}$ & $* *$ \\
Palmitic Acid (\%) & C16:0 & $7.99 \pm 0.02 \mathrm{~b}$ & $8.70 \pm 0.02 \mathrm{a}$ & $* *$ \\
Margaric acid (\%) & $\mathrm{C} 17: 0$ & $0.10 \pm 0.00 \mathrm{a}$ & $0.09 \pm 0.01 \mathrm{a}$ & N.S \\
stearic acid (\%) & $\mathrm{C} 18: 0$ & $5.72 \pm 0.03 \mathrm{a}$ & $4.79 \pm 0.02 \mathrm{~b}$ & $* *$ \\
Arachidic acid (\%) & $\mathrm{C} 20: 0$ & $0.15 \pm 0.01 \mathrm{~b}$ & $0.18 \pm 0.01 \mathrm{a}$ & $* *$ \\
Behenic acid (\%) & $\mathrm{C} 22: 0$ & $0.12 \pm 0.02 \mathrm{a}$ & $0.09 \pm 0.01 \mathrm{~b}$ & $* *$ \\
Lignoceric acid (\%) & $\mathrm{C} 24: 0$ & $0.13 \pm 0.01 \mathrm{a}$ & $0.08 \pm .0 .01 \mathrm{~b}$ & $* *$ \\
Total Saturated Fatty Acid (SFA) (\%) & & 14.33 & 14.02 & \\
palmitoleic Acid (\%) & $\mathrm{C} 16: 1$ & $0.10 \pm 0.01 \mathrm{a}$ & $0.10 \pm 0.01 \mathrm{a}$ & N.S \\
Heptadecanoic acid (\%) & $\mathrm{C} 17: 1$ & $0.10 \pm 0.01 \mathrm{a}$ & $0.09 \pm 0.01 \mathrm{a}$ & N.S \\
Oleic Acid (\%) & $\mathrm{C} 18: 1$ & $17.49 \pm 0.05 \mathrm{a}$ & $17.42 \pm 0.04 \mathrm{a}$ & N.S \\
Oleic Acid (\%) & $\mathrm{C} 18: 1$ trans & 0 & 0 & - \\
Eicosenoic acid (\%) & $\mathrm{C} 20: 1$ & $0.14 \pm 0.01 \mathrm{a}$ & $0.13 \pm 0.01 \mathrm{a}$ & N.S \\
Erucic acid (\%) & $\mathrm{C} 22: 1$ & 0 & 0 & - \\
Mono Unsaturated Fatty Acid & & 17.83 & 17.74 & \\
(MUFA) (\%) & & & & \\
Linoleic Acid (\%) & $\mathrm{C} 18: 2$ & $67.06 \pm 0.09 \mathrm{~b}$ & $67.79 \pm 0.03 \mathrm{a}$ & $* *$ \\
Linoleic Acid (\%) & C18:2 trans & 0 & 0 & - \\
$\gamma$-Linolenic acid (\%) & $\mathrm{C} 18: 3$ & $0.78 \pm 0.01 \mathrm{a}$ & $0.45 \pm 0.01 \mathrm{~b}$ & $* *$ \\
Poly Unsaturated Fatty Acid (PUFA) & & 67.84 & 68.24 & \\
(\%) & & $8.92 \pm 0.09 \mathrm{a}$ & $7.02 \pm 0.08 \mathrm{~b}$ & $* *$ \\
Total Oil Content (\%) & & $70.008 \pm 0.89 \mathrm{~b}$ & $84.127 \pm 0.79 \mathrm{a}$ & $* *$ \\
Total Phenolic Substance Content (mg & & & & \\
GAE/kg extract) & & & & \\
\hline$* *$ Significant at p $<0.01$, N.S.: Non-Significant & & &
\end{tabular}

Other fatty acids detected in the study include myristic acid (C14: 0), margaric acid (C17: 0), arachidic acid (C20: 0), behenic acid (C22: 0), lignoceric acid (C24: 0), palmitoleic acid (C16: 1), margaroleic acid (C17: 1), eicosanic acid (C20: 1) and $\gamma$-linolenic acid (C18: 3). Although there are statistical differences between varieties, these fatty acids are quite low. Erucic acid (C22: 1) was not identified in either of the varieties. Among the trans oils, linoleic acid (C18: 2 trans) and oleic acid (C18: 1 trans) were not found (Table 1). Total phenolic substance content ranges between 70 and 84 (mg GAE/kg extract) among the varieties. The phenolic content of the Dimrit grape seed is higher than that of the other species. 
As reported from previous studies, grape seed oil mainly contains palmitic, stearic, oleic and linoleic acids $[24,25]$. In one study researcher reported that the ranges of fatty acids in the seeds of five grape variety were $6.7-8.9 \%$ for palmitic, $1.1-5.3 \%$ for stearic, $9.7-17.5 \%$ for oleic, $69.2-80.5 \%$ for linoleic and less than $0.1 \%$ for palmitoleic and linolenic acids [26]. The fatty acid composition of the grape seed oil is between the oils of safflower, sunflower, soybean, maize, cotton seed, poppy and tabacco [27]. It has been stated that sunflower oil and grape seed oil show similarity in many studies. Sunflower oil includes $60 \%$ linoleic, $25 \%$ oleic, $8 \%$ palmitic and 5\% stearic acid [27]. Grape seed oil fatty acid composition is very similar to sunflower oil.

Luttero et al. were studied cold-pressed chardonnay, muscadine, ruby red, and concord grape seed oils and their defatted flours for their fatty acid composition. The most abundant fatty acid in the oils was linoleic acid, ranging from $66.0 \mathrm{~g} / 100 \mathrm{~g}$ of total fatty acids in ruby red seed oil to $75.3 \mathrm{~g} / 100 \mathrm{~g}$ of total fatty acids in concord seed oil. The oils were also high in oleic acid and low in saturated fat [28]. When these values are examined, it is seen that the values we find overlap with the literature.

When the literature is examined, it is seen that the total phenolic contents are incompatible with each other [29-31]. In all plant metabolisms, there are many different qualities and quantities of phenolic compounds known as secondary metabolites, which are known to play roles in protecting plants against certain harmful organisms [32]. The structure and amount of phenolic compounds varies depending on the phenological grades the grapes have undergone during maturation. The amount of phenolic compounds in the seed decreases in the later stages from the maturation phase. The amount of phenol compounds in the grapes varies according to the variety and maturation, the environmental factors (climate, soil, etc.), and the applied cultural processes [33].

Grape grown in Turkey, especially grapes in the Aegean region are consumed as table. The quality of the grapes grown in the Cappadocia region is not suitable for consumption as table. Thin crustaceans and juicy fruit meats make these grapes used in the wine industry. The wines made are not included in the top-quality group. Because of their religious beliefs, some producers do not sell their products for wine production, but use them in making food products such as molasses and pulp. This situation causes a high amount of stem, nucleus and crust from the grapes grown in the Cappadocia region. According to these results, the oils of Cappadocia grape varieties Emir and Dimrit can be proposed as a new food source for human nutrition at the same time to contribute to the reduction of factory product costs. 


\section{CONCLUSION}

It is known that grape seeds have a strong antioxidant and free radical scavenging effect due to their proanthocyanidins. Hardness and negative taste make the grape seed not suitable for direct consumption and this makes the grape seed oil more valuable. On the other hand, from these seeds, which are the by-products of the wine industry, polyphenols can easily be extracted in large quantities, enabling their application as ingredients of functional or enriched foods.

\section{REFERENCES}

[1] D. Bagchi, M. Bagchi, S.J. Stohs, S.D. Ray, C.K. Sen, H.G. Preuss, Cellular protection with proanthocyanidins derived from grape seeds. Ann. N.Y. Acad. Sci. 957(1) (2002) 260-270.

[2] S.G. Tangolar, Y. Ozoğul, S. Tangolar, A. Torun, Evaluation of fatty acid profiles and mineral content of grape seed oil of some grape genotypes. Int. J. Food Sci.Nutr. 60(1) (2009) 32-39.

[3] E.B. Özvural and H. Vural, Kırmızı Üzüm Çekirdeği Unu ve Yă̆ının Sosislerin Kalite Kriterleri Üzerine Etkisi. Türkiye 10. G1da Kongresi Prooceeding Book, pp. 21-23, 21-23 Mayıs 2008, Erzurum, Turkey.

[4] J.A. Nowshehri, Z.A. Bhat, M.Y. Shah, Blessings in disguise: Bio-functional benefits of grape seed extracts. Food Rev. Int. 77(3) (2015) 333-348.

[5] S. Bail, G. Stuebiger, S. Krist, H. Unterweger, G. Buchbauer, Characterisation of various grape seed oils by volatile compounds, triacylglycerol composition, total phenols and antioxidant capacity. Food Chem. 108(3) (2008) 1122-1132.

[6] M.N. Clifford, Anthocyanins-nature, occurrence and dietary burden. J. Sci. Food Agr. 80(7) (2000) 1063-1072.

[7] B. Matthäus, Virgin grape seed oil: Is it really a nutritional highlight? Eur. J. Lipid Sci. Tech. 110(7) (2008) 645-650.

[8] W.M. Thomas, E.D. Nicholas, J.C. Needham, M.G. Murch, P. Temple-Smith and C.J. Dawes: International Patent Application PCT/GB92/02203 and GB Patent Application 9125978.8, UK Patent Office, London, December 6, 1991.

[9] G. Jayaprakasha, T. Selvi, K. Sakariah, Antibacterial and antioxidant activities of grape (Vitis vinifera) seed extracts. Food Res. Int. 36(2) (2003) 117-122.

[10] M. Shafiee, M.A. Carbonneau, N. Urban, B. Descomps, C.L. Leger, Grape and grape seed extract capacities at protecting LDL against oxidation generated by $\mathrm{Cu} 2+$, AAPH or SIN1 and at decreasing superoxide THP-1 cell production. A comparison to other extracts or compounds. Free Radic. Res. 37(5) (2003) 573-584.

[11] M. Pinent, M. Blay, M.C. Bladè, M.J. Salvadó, L. Arola, A. Ardèvol, Grape seed-derived procyanidins have an antihyperglycemic effect in streptozotocin-induced diabetic rats and insulinomimetic activity in insulin-sensitive cell lines. Endocrinology 145(11) (2004) 49854990.

[12] M.J.R.Vaquero, M.R. Alberto, M.C.M. de Nadra, Influence of phenolic compounds from wines on the growth of Listeria monocytogenes. Food Control 18(5) (2007) 587-593.

[13] Y. Nakamura, S. Tsuji, Y. Tonogai, Analysis of proanthocyanidins in grape seed extracts, health foods and grape seed oils. J. Health Sci. 49(1) (2003) 45-54. 
[14] S.-Y. Kim, S.-M. Jeong, W.-P. Park, K.C. Nam, D.U. Ahn, S.-C. Lee, Effect of heating conditions of grape seeds on the antioxidant activity of grape seed extracts. Food Chem. 97(3) (2006) 472-479.

[15] W. Horwitz, P. Chichilo, H. Reynolds, Official methods of analysis of the Association of Official Analytical Chemist (Association of Analytical Chemists, Washington, 1970).

[16]D. Pearson, The chemical analysis of foods (Longman, Harlow, 1976).

[17]S. Jung, D.A. Rickert, N.A. Deak, E.D. Aldin, J. Recknor, L.A. Johnson, P.A. Murphy, Comparison of Kjeldahl and Dumas methods for determining protein contents of soybean products. J.Am. Oil Chem Soc. 80(12) (2003) 1169-1173.

[18] S. Ranganna, Handbook of analysis and quality control for fruit and vegetable products. (McGraw-Hill Education, New York, 1986).

[19]W. Praznik, N. Mundigler, A. Kogler, B. Pelzl, A. Huber, M. Wollendorfer, Molecular background of technological properties of selected starches. Starch-Stärke 51(6) (1999) 197-211.

[20]H. Slover, E. Lanza, Quantitative analysis of food fatty acids by capillary gas chromatography. J. Am. Oil Chem. Soc. 56(12) (1979) 933-943.

[21] K. Slinkard, V.L. Singleton, Total phenol analysis: automation and comparison with manual methods. Am. J. Enol. Viticult. 28(1) (1977) 49-55.

[22] N. Yıldız, H. Bircan, Araştırma ve deneme metodları (Problemler ve çözümleri) (Atatürk Üniversitesi, Erzurum, 1992)

[23]L. Bravo, F. Saura-Calixto, Characterization of dietary fiber and the in vitro indigestible fraction of grape pomace. Am. J. Enol. Viticult. 49(2) (1998) 135-141.

[24]L.J.R. Barron, M.V. Celaè, G. Santa-Maria, N. Corzo, Determination of the triglyceride composition of grapes by HPLC. Chromatographia 25(7) (1988) 609-612.

[25] W.H. Schuster, R.A. Marquard, Ölpflanzen in Europa (DLG-Verlag, Frankfurt, 1992)

[26] M. Ohnishi, S. Hirose, M. Kawaguchi, S. Ito, Y. Fujino, Chemical composition of lipids, especially triacylglycerol in grape seeds. Agr. Biol. Chem. 54(4) (1990) 1035-1042.

[27]E. Weiss, Oil seed crops. Tropical agricultural series. (Longman, London, 1983).

[28]H. Lutterodt, M. Slavin, M. Whent, E. Turner, L.Yui, Fatty acid composition, oxidative stability, antioxidant and antiproliferative properties of selected cold-pressed grape seed oils and flours. Food Chem. 128(2) (2011) 391-399.

[29]M. Özden and H. Vardin, Şanlıurfa Koşullarında Yetiştirilen Bazı Şaraplık Üzüm Çeşitlerinin Kalite ve Fitokimyasal Özellikleri. J. Agric. Fac. HR. U. 13(2) ( 2009) 21-27.

[30]N.G. Baydar, G.Özkan, S. Yaşar, Evaluation of the antiradical and antioxidant potential of grape extracts. Food Control 18(9) (2007) 1131-1136.

[31]G. Özkan, O. Sağdıç, N. Göktürk-Baydar, Antibacterial effect of narince grape (Vitis vinifera L.) pomace extract. Selcuk J. Agr. Food Sc., 17(32) (2003) 53-56.

[32] İ. Saldaml, Gida Kimyası. (Hacettepe Üniversitesi, Ankara, 2007).

[33]P. Ribéreau-Gayon, Y. Glories, A. Maujean, D. Dubourdieu, Handbook of Enology: The Chemistry of Wine Stabilization and Treatments. Vol. 2, $2^{\text {nd }}$ Ed. (John Wiley\&Sons, Chichester, 2000). 